\title{
Pendidikan Moral Anak Usia Dini Berbasis Kearifan Lokal dalam Keluarga
}

\author{
Musyafa Ali ${ }^{\bowtie}$, Riyanti², Umi Khomsiyatun ${ }^{3}$ \\ Pendidikan Islam Anak Usia Dini, Universitas Islam Negeri Sunan Kalijaga Yogyakarta, \\ Indonesia(1); Studi Islam, Universitas Islam Negeri Prof. K.H. Saifuddin Zuhri Purwokerto, \\ Indonesia(2); Pendidikan Guru Madrasah Ibtidaiyah, Universitas Islam Negeri Prof. K.H. \\ Saifuddin Zuhri Purwokerto, Indonesia (3) \\ DOI: $\underline{10.31004 / \text { obsesi.v6i3.2020 }}$
}

\begin{abstract}
Abstrak
Mendidik anak agar memiliki moral yang baik bukanlah hal yang instan, hal tersebut harus dilakukan mulai dari lingkup pendidikan dan sosial terkecil, yakni keluarga. Tujuan dari penelitian ini untuk mengetahui bagaimana orangtua mendidik moral anak usia dini dalam keluarga berbasis kearifan lokal. Penelitian ini dilakukan di lingkup keluarga yang berada di Desa Cikakak, sampel dalam penelitian ini yakni ada lima keluarga dimana dua keluarga juru kunci dan tiga keluarga disekitar masjid Saka Tunggal. Jenis penelitian ini merupakan penelitian lapangan, dalam pengumpulan data, peneliti menggunakan teknik wawancara. Dalam menganalisis dat peneliti menggunakan teknik Miles dan Huberman yakni dimulai dengan reduksi data, penyajian data dan verifikasi data. Hasil dari penelitian ini menunjukan bahwasanya pendidikan moral dilakukan melalui dua tradisi yakni tradisi berupa praktik dan tradisi lisan. Dari dua tradisi tersebut terdapat beberapa nilai moral yang diajarkan yakni nilai toleransi atau menghargai orang lain, kebersamaan dan saling berbagi, saling memaafkan, bekerjasama, gotong royong dan menghilangkan sifat iri, sombong (sifat buruk dalam diri), kepedulian (peduli pada alam), penghormatan (menghormati), jujur, tidak serakah, dan bertanggung jawab.

Kata Kunci: pendidikan moral; anak usia dini; keluarga, kearifan lokal
\end{abstract}

\begin{abstract}
Educating children to have good morals is not an instant thing, it must be done starting from the smallest educational and social scope, namely the family. The goal of the study was to find out how parents educate early childhood morals in families based on local wisdom. This study was conducted in the scope of families located in Cikakak Village, the sample in this study was that there were five families where two caretaker families and three families around Saka Tunggal mosque. This type of research is field research, in data collection, researchers use interview techniques. In analyzing dat researchers using miles and huberman techniques, it starts with data reduction, data presentation and data verification. The results of this study show that moral education is carried out through two traditions, namely traditions in the form of oral practices and traditions. From the two traditions there are several moral values that are taught, namely the value of tolerance or respect for others, togetherness and sharing, mutual forgiveness, cooperation, mutual cooperation and eliminating envy, pride (bad nature in self), caring (caring for nature), respect (respect), honesty, not greedy, and responsible.
\end{abstract}

Keywords: morals; early childhood; family, local wisdom

Copyright (c) 2022 Riyanti, et al.

$\square$ Corresponding author:

Email Address : musyafaali176@gmail.com (Purwokerto, Jawa Tengah, Indonesia)

Received 27 September 2021, Accepted 30 December 2021, Published 14 January 2022 


\section{PENDAHULUAN}

Dari data KPAI tahun 2019 jumlah anak Indonesia yang bermasalahan dengan hukum mencapai 1.251 dimana mereka ditindak pidana karena kasus dan penggunaan napza dan pada anak-anak mencapai 344 kasus (Medcom.id, 2021). Hal ini menjadi sebuah keprihatinan bagi bangsa Indonesia pasalnya sepuluh tahun kedepan merkalah yang akan melanjutkan keberlangsungan bangsa ini (Ramadhan, Marlina, and Isnaini, 2020; Fitri, Riana, and Fedryansyah, 2015). Setiap hari kita disajikan dengan berita-berita tentang kenakalan remaja, mulai dari pencurian, pembunuhan, balap liar, narkoba dan lain sebagainya. Hal ini menunjukan bahwasanya terjadinya degradasi moral dikalangan remaja Indonesia.

Untuk membentuk moral yang baik bukan lah hal yang mudah dan instan. Untuk menjadikan anak memiliki moral yang baik, orangtua perlu mendidik dan mengajarkan pada anak sejak dini. Pendidikan moral harus dilakukan mulai dari lingkup pendidikan dan sosial terkecil yakni keluarga. Disinilah peran penting orang tua sebagai pemegang kunci sekaligus pembentuk moral anak (Boiliu and Polii, 2020; Satya Yoga, Suarmini, and Prabowo, 2015). Anak merupakan hasil imitasi dari orang tua, oleh karena itu orang tua sebagai pendidik dalam lingkup keluarga berperan besar dalam pembentukan moralitas anak (Barida, 2016; Ulumudin, 2020).

Dalam kehidupan bermasyarakat moralitas sering diartikan dengan baik buruk tingkah laku atau perbuatan seseorang. Seseorang dikatakan memiliki moral yang baik ketika dalam bermasyarakat ia sopan, baik dan suka menolong, begitu pun sebaiknya, ketika seseorang dikatakan tidak sopan atau kurang baik maka ia memiliki moral yang buruk (Surawati, Sri Winarti, and Dwipayana, 2019). Dalam tahap perkembangan moralitas anak yakni anak sudah mengetahui mana hal baik dan buruk, mana yang boleh dan tidak boleh dilakukan (Desmita, 2012). Moralitas anak terbentuk oleh beberapa faktor diantaranya yakni lingkungan baik internal (keluaraga) atau eksternal, adat istiadat, kebiasaan, dan tradisi setempat (Tridhonanto, 2014). Hal ini menunjukan bahwsanya moralitas seseorang dipengearuhi oleh lokalitas sebuah daerah tersebut, ketika anak dibesarkan didaerah yang masih menjunjung tinggi nilai-nilai budaya maka moral anak akan terbentuk sebagai insan yang menghargai dan menghormati lokalitas tersebut.

Tidak dipungkiri bahwasanya kearifan lokal atau budaya lokal berpengaruh terhadap nilai-nilai atau normal moral seseorang. Anak yang bibesarkan oleh keluarga yang masih menjunjung tinggi adat-stiadat serta kepercayaan setempat biasanya itu nilai-nilai itu juga akan diajarkan dan diturunkan kepada anak-anaknya (M. Fitri \& Na'imah, 2020; Rachmawati, 2020). Sebagai contoh jika orang tua masih menggunakan bahasa jawa halus dalam berbahasa atau berkomunikasi sehari-hari makan kemungkinan besar anakpun akn seperti itu, saat orang tua masih aktif dalam mengikuti kegiatan ritual baik kejawen atau keagamaan maka secara langsung biasanya anak akan mengikuti kebiasaan tersebut.

Kearifan lokal sebagai warisan leluhur memiliki peranting dalam kehidupan seharihari, termasuk didalamnya mengandung nilai-nilai moral (PDSPK, 2016). Sebagai contoh dalam sebuah tradisi lisan "ora olih ngomong saru" atau dalam bahasa Indonesia tidak boleh berkata kotor, dari kata tersebut terdapat nilai moral yang dapat diajarkan pada anak, yakni sopan santun dan menghormati. Dari tradisi tari kita bisa mengajarkan makna-makna yang terkandung dalam gerakan dan lirik lagunya, seperti contoh tari campak dimana tari campak dari melayu menggambarkan kebahagiaan masyarakat Melayu Bangka akan datangnya hari raya panen. Dalam tarian dan lirik lagu tersebut terdapat nilai-nilai moral sosial, yakni berbagi (Ananda, 2021). Kearifan lokal tersendiri dibagi menjadi dua jenis yakni yang terlihat seperti peninggalan berupa benda, atau bangunan. Sedangkan kearifan lokal yang tidak nampak yakni berupa nilai-nilai, gagasan, norma serta kebiasaan-kebiasaan yang dilakukan oleh orang terdahulu. Selain itu kearifan lokal juga dapat dibagi menjadi dua yakni kearifan lokal yang berupa tindakan atau kegiatan yang dilakukan dan perkataan (tradisi lisan) (Koentjaraningrat, 1990). 
Penelitan terdahulu terkait pendidikan moral telah banyak dilakukan diantaranya penelitian yang dilakukan oleh Abdul Rozaq. Adapun judul penelitian yang dilakukan yakni Pendidikan Moral Anak Pilar Utama Dalam Keluarga, hasil dari penelitian yang dilakukan yakni Anak adalah imitasi dari apa yang dilakukan oleh orang tua dan lingkungannya. Maka dari itu keluarga sebagai lembaga pendidikan bagi anak harus mampu menjadi lingkungan yang baik dan orang tua sebagai pendidik harus mampu menjadi teladan bagi anak. Hal ini dikarenakan anak membutuhkan tindakan atau contoh secara langsung bukan hanya sekedar cerita (Rozaq, 2013). Penelitian lain juga dilakukan oleh Mulianah Khaironi, dengan judul penelitiannya yakni Pendidikan Moral Pada Anak Usia Dini. Hasil dari penelitiannya menunjukan bahwasanya dalam mendidik moral anak harus dilakukan oleh semua pihak, baik dari lingkungan keluarga, masyarakat dan pendidikan. Dimana guru dan orang tua merupakan role model bagi anak, sehingga guru dan orang tua harus mampu menjadi role model yang baik (Khaironi, 2017).

Penelitian lain dilakukan oleh Wuri Wuryandani dengan judul penelitiannya yakni Peranan Keluarga Dalam Menanamkan Nilai Moral Pada Anak Usia Dini. Hasil dari penelitiannya menunjukan ketika orang tua ingin medidik moral anak, orang tua harus memperhatikan beberapa hal, yakni orang tua harus tahu terlebih dahulu nilai apa yang akan ditanamkan pada anak, orangtua harus mampu jadi teladan, dan konsekuen atas apa yang diterapkan (Wuryandani, 2010). Penelitian selanjutnya dilakukan oleh Mardi Fitri dan $\mathrm{Na}$ 'imah dengan judul penelitiannya yakni Faktor Yang Mempengaruhi Perkembangan Moral Pada Anak Usia Dini. Hasil penelitian yang dilakukan yakni terdapat dua faktor yang mempengaruhi perkembangan moral anak, yakni faktor internal dan faktor eksternal (Fitri and Na'imah, 2020).

Dari berbagai penelitian terdahulu yang telah dilakukan, peneliti tertarik untuk melakukan penelitian terkait Pendidikan Moral Anak Usia Dini Dalam Keluarga Berbasis Kearifan Lokal. Perbedaan penelitian ini dengan penelitian terdahulu yakni dimana kearifan lokal menjadi dasar atau nilai yang digunakan oleh keluarga guna membentuk moralitas anak. Penelitian ini didasarkan pada nilai-nilai kearifan lokal sebagai warisan leluhur penting untuk tetap dilistarikan dan dikenalkan pada anak sejak dini. Selain itu kearifan lokal memiliki nilainilai luhur yng dapat menjadi media pendidikan moral bagi anak. Penelitian ini dilakukan di Desa Cikakak Kecamatan Wangon, Kabupaten Banyumas. Hal ini didasarkan pada masyarakat Desa Cikakak yang hingga saat ini masih mempertahankan tradisi leluhur dan nilai-nilai kearifan lokal dalam kehidupan sehari-hari.

\section{METODOLOGI}

Penelitian ini merupakan penelitian lapangan, dengan menggunakan pendekatan deskriptif kualitatif (Moleong, 2016). Penelitian ini dilakukan di lingkup keluarga yang berada di Desa Cikakak, sampel dalam penelitian ini yakni ada lima keluarga dimana dua keluarga juru kunci dan tiga keluarga disekitar masjid Saka Tunggal. Sumber informasi dalam penelitian ini yakni orang tua yang memiliki anak usia dini dan orang tua (sesepuh). Dalam pengumpulan data peneliti menggunakan teknik wawancara secara langsung, hal ini bertujuan agar peneliti mendapat informasi yang akurat. Adapun dalam menganalisis data peneliti menggunakan teknik Miles dan Huberman yakni dimulai dengan reduksi data, penyajian data dan verifikasi data (Miles, 2005).

\section{HASIL DAN PEMBAHASAN}

Kearifan lokal sebagai warisan leluhur memiliki peranting dalam kehidupan seharihari, termasuk didalamnya mengandung nilai-nilai moral (Dokhi, 2016). Desa Cikakak menjadi salah satu desa di Banyumas yang identik dengan masyarakat kejawen, dimana masyarakat masih meyakini tradisi-tradisi yang diturunkan oleh para leluhur. Dan hingga saat ini tradisi-tradisi atau warisan tradisi tersebut masih terus dijalankan, masyarakat desa Cikakak percaya bahwasanya warisan tersebut memiliki nilai-nilaiyang syarat akan kebaikan 
jika dilakukan dan jika ditinggalkan akan membawa dampak buruk. Diantara nilai-nilai yang ada dalam tradisi yang hingga saat ini masih dilakukan yakni nilai sosial, humanis, moral, agama dan mistis. Nilai-nilai tersebut diajarkan secara turun temurun kepada generasi penerus melalui pendidikan dilingkup terkecil yakni keluarga. Adapun kearifan lokal yang menjadi dasar pendidikan moral pada anak usia dini dalam keluarga yakni tradisi berupa praktik dan tradisi lisan.

\section{Tradisi Praktik}

Tradisi berupa praktik yakni tradisi yang diajarkan oleh orang tua melalui praktikprakti atau kegiatan yang dilakukan oleh masyarakat, baik praktik kebudayaan ataupun praktik keagamaan (Koentjaraningrat, 2000). Adapun tradisi praktik yang dilakukan oleh orang tua guna mendidik moral anak usia dini yakni:

\section{Idhul Idhi}

Lebaran atau masyarakat aboge menyebutnya dengan leburan atau orang umum menyebutnya dengan hari raya idul fitri. Umumnya lebaran masyarakat aboge adalah yang terakhir, setelah biasanya diawalai oleh Muhammadiyah kemudian NU dan disusul masyarakat aboge. Namun perayaan masyarakat aboge sama seperti masyarakat pada umumnya. Dimana dipagi hari seluruh masyarakat mulai dari anak-anak hingga orangtua berbondong-bondong menuju masjid saka tunggal sambil membawa tumpengan. Setelah semua masyarakat berkumpul kemudia melaksanakan sholat idul fitri, setelah salat selesai kemudian masyarakat aboge akan menyantap tumpengan atau dalam masyarakat aboge bias menyebutnya dengan kepungan bersama, setelah itu baru kemudian acara salam bekti atau bersalam-salaman untuk saling meminta maaf. Setelah salam-salaman atau salam bekti selesai biasanya masyarakat akan berbondong-bondong kerumah sanak saudara dan tetangga sambil membawa makanan atau berbagi makanan, hal ini dilakukan tidak hanya masyarakat islam aboge akn tetapi juga dilakukan oleh masyarakat Muhammadiyah ataupun NU. Selain itu dalam proses salat ied juga diikuti oleh masyarakat Muhammadiyah dan juga NU. Sehingga seluruh masyarakat berbaur tanpa memandang aliran.

Dari tradisi idul idhi ini orang tua mengajarkan nilai moral toleransi atau menghargai orang lain, kebersamaan dan saling berbagi, dan saling memaafkan. Melalui tradisi idhul idhi ini orang tua mengajarkan pada anak bahwasanya anak harus menghargai perbedaan, dalam hal ini perbedaan waktu berpuasa, lebaran dan perbedaan aliran hal ini diajarkan melalui perbedaan aliran. Kemudian anak juga diajarkan kebersamaan dan saling berbagi, hal ini diajarkan oleh orangtua pada anak saat kepungan dimana anak akan diajak makab bersama dengan orang lain yang berbeda usia. Dan saling memaafkan diajarkan saat tradisi salam bekti, dimana anak diajarkan untuk meminta maaf dan memaafkan kesalahan yang pernah dilakukan oleh orang lain.

\section{Ganti Jaro atau Rajabiyah}

Tradisi ganti jaro atau rajabiyah merupakan tradisi mengganti pagar bambu. Kegiatan ini dilakukan oleh warga penganut islam aboge dimana yang ikut tidak hanya penganut aboge dari Desa Cikakak, melainkan penganut kepercayaan aboge dari luar daerah. Dimana sejak pagi warga datang dengan berbondong-bondong baik orang tua hingga anak-anak hadir dalaam acara tersebut. Dimana kedatangan warga bertujuan untuk mengganti pagar bambu yang ada di sekitar makam mbah mustolih dan masjid saka tungga. Dalam acara tersebut warga datang dengan membawa satu bilah bambu panjang dari rumah masing-masing. Dalam pelaksanaan tradisi ini terdapat beberapa pantangan yang tidak boleh dilanggar oleh masyarakat yang datang, yakni warga tidak boleh menggunakan nada tinggi saat berbicara serta tidak boleh mengenakan alas kaki, sehingga selama proses penggantian pagar ataau ganti jaro yang terdengan hanya suara-suara bambu yang dibersihkan. Dibelah, dipukul dan lain sebagainya. 
Tradisi ini dilakukan satu tahun sekali, dimana biasanya hanya dilakukan dalam waktu satu hari, dengan panjang pagar sekitar 300 meter, dan warga yang datang biasanya lebih dari seratus orang. Setelah proses penggantian pagar selesai biasanya warga akaan melanjutkan kegiatannya dengan proses doa bersama di makam kyai mustolih, kemudian dilanjutkan salat sunnah bersama, dan diakhiri dengan warga mengarak lima gunung tumpeng yang kemudian di perebutkan pada warga yang hadir.

Makna dari kegiatan ganti jaro yakni kebersamaan dan gotong royong, yang dimana hal ini diyakini oleh masyarakat aboge sebagai salah satu media menghilangkan sifat jahat, iri, dan sifat tidak baik pada diri manusia. Selain itu kegiatan ini juda menjadi media mendekatkan diri pada Allah SWT, sekaligus sebagai bentuk rasa syukur masyarakat atas hasil bumi yang telah diperoleh selama satu tahun tersebut. tradisi arakan tumpeng menjadi penutup dengan makna yang diyakini oleh masyarakat yakni bahwasanya tumpengan tersebut membawa keberkahan.

Dari tradisi ganti jaro ini orang tua mengajarkan nilai moral bekerjasama, kebersamaan, gotong royong dan menghilangkan sifat iri, sombong dan lain sebagainya yang berkaitan dengan sifat buruk. Nilai moral kerjasama dan gortong royong diajarkan oleh orangtua dengan cara orang tua mengajak anak untuk melihat orang tua bekerjasama dalam mengganti pagar yang lama dengan yang baru, dimana setiap orang memiliki tugas yang berbeda untuk satu tujuan. Nilai moral kebersamaan ditunjukkan oleh orang tua saat orangorang atau masyarakat datang berbondong-bondong ke masjid saka tunggal dengan membawa bambu, kemudian disama saat perebutan tumpengan dan salat sunnah. Kemudian nilai moral agar tidak iri, tidak sombong diajarkan pada anak melalui kegiatan ganti pagar dan perebutan tumpengan, perebutan tumpengan ini biasanya ada orang yang dapat banyak dan adapula yang dapat sedikit, sehingga dari perebutan ini anak akan belajar untuk tidak iri, dengan apapun yang didapatkan dan tidak sombong jika mendapatkan lebih banyak daripada orang lain.

\section{Rebo Wekasan}

Rebo wekasan merupakaan peringatan hari rabu terakhir dibulan sa'ban. Untuk tradisi ini sendiri sebenarnya dilakukan dipertengahan bulan sya'ban dimana masyarakat aboge meyakini malam itu merupakan malam pelapopran amal selama setahun kepada Allah SWT. Oleh karena itu masyarakat harus melakukan amal ibadah sebagai penutup laporan akhir tahun. Pelaksanaan ibadah dilakukan di Masjid saka tunggal secara bersama-sama dengan melaksanakan salat maghrib berjamaah, kemudian membaca surah Yaasiin sebanyak tiga kali, bacaan pertama untuk memohon pengampunan atas dosa yang telah dilakukan selama satu tahun, bacaan kedua ditujukan untuk meminta panjang umur dan umur yang berkah sedangkan untuk bacaan ketiga untuk meminta kelapangan rezeki.

Sebelum acara inti yang jatuh pada pertengahan bulan sya'ban sebenarnya ada beberapa tradisi yang harus dilakukan pula oleh masyarakat yakni masyarakat akaan mengadakan acara ruwatan atau slametan. Selain itu pada tanggal limabelas sya'ban dipagi harinya biasanya juga akan diadakan tahlilan dimana dalam tahlilan ini masyarakat biasanya akan diberikan doa tolak bilahi, guna dimasukkan kedalam bak kamar madi, kemudian mandi dengan air yang ada didalam bak tersebut, masyarakat aboge percaya hal itu sebagai salah satu bentuk usaha untuk membasuh dan menghilangkan kejahatan yang melekat dalam diri manusia. Tradisi ini diakhiri dengan salat berjamaan dan tahlil dengan menghadap empat penjuru mata angin (saka tunggal yang ada di dalam masjid saka tunggal).

Dari tradisi rebo wekasan ini orang tua mengajarkan nilai moral yang berkaitan dengtan ketuhanan yakni keimanan dan ketakwan. Hal itu tercermin dari kepercyaan sekaligus ketundukan masyarakat akan kebesaran tuhan. Selain itu bentuk penutupan laporan juga menjadi tradisi yang dipercaya oleh masyarakat aboge, sehingga masyarakat harus melakukan kebaikan agar catatan amal selaa satu tahun juga dicatat baik. Kemudian pembacaan surat yaasiin sebanyak tiga kali dan doa tolak bilahi sebagai simbol guna 
meningkatkan ketakwaan masyarakat aboge pada tuhannya. Tradisi ini tidak hanya dilakukan oleh orang tua akan tetapi juga dilakukan oleh anak-anak yang diajak oleh orang tuanya.

\section{Sedekah Bumi}

Tradisi sedekah bumi merupakan tradisi arak-arakan dengan membawa tenong yang berisi tumpengan yang berisi lauk pauk, buah dan hasil bumi lainnya sebagai simbol penghormatan kepada Nabi dan Rasul serta simbol persatuan antar umat manusia. Tradisi ini dilakukan secara bersama-sama oleh seluruh masyarakat mulai dari anak-anak hingga orangtua. Kegiatan diawali dengan resik-resik atau membersihkan desa dan dilanjutkan membersihkan makam sebagai penghormatan pada leluhur. Setelah itu warga biasanya akan berkumpul di perempatan jalan desa, hal ini dikarenakan perempatan jalan desa merupakan persimbolan empat penjuru leluhur untuk mencapai kemunggalan kepada Tuhan. Setelah warga berkumpul kemudian acara arak-arakan tumpenganpun dilaksanakan. Arak-arakan dipimpin oleh juru kunci dimana juru kunci harus mengenakan pakaian adat dengan warna hitam, menyiapkan sajen atau sesaji serta kepala kambing (kepala kambing biasanya hanya diganti dengan tulang belulang, hanya sebagai bentuk perwujudan). Sesaji kemudian ditaruh di sudut perempatan dengan kemenyan yang dibakar dan kepala kambing diletakkan di sudut perempat penjuru mata angin. Setelah itu doa pun dipanjatkan, doa yang dipanjatkan oleh juru kunci menggunakan dua bahasa yakni bahasa jawa dan bahasa arab dan diakhiri dengan makan bersama.

Tujuan utama dari tradisi ini yakni untuk membersihkan desa dari berbagai bentuk dosa yang telah dilakukan oleh masyarakat. Selain itu tradisi ini juga menjadi lambang bentuk rasa syukur masyarakat atas apa yang telah diperoleh atau diberikan oleh bumi pada masyarakat. Dengan adanya tradisi ini masyarakat percaya bahwasanya rezeki yang dihasilkan akan menjadi lebih berkah, kebrersamaan atau kerukunan dengan sesama juga akan lebih erat.

Dari tradisi sedekah bumi ini nilai moral yang dapat diajarkan pada anak yakni diantaranya, nilai kebersamaan, nilai gotong royong dan nilai kepedulian. Nilai-nilai tersebut tercermin dari kegiatan resik-resik bersama, pembawaan tenong yang berisi tumpengan yang berisi lauk pauk, dan acara makan bersama diakhir acara.

\section{Jaroh Makom}

Jaroh makom atau ziarah makam merupakan tradisi berziarah mengunjungi makam leluhur untuk mengirimkan doa kepada para leluhur. Jaroh makom biasa dilakukan oleh masyarakat aboge baik anak-anak hingga dewasa, biasanya ziarah dilakukan bersama anggota keluarga dan kerabat. Masyarakat aboge percaya bahwasanya dengan berziarah dan mengirim doa kepada leluhur maka leluhur juga akan menolongnya atau memberi perolongan pada anak cucunya. Tradisi ini biasa dilakukan di bulan sya'ban ataupun harihari tertentu seperti hari jum'at, dengan cara berkunjung dan mengirimkan doa berupa tahlil. Hari jum'at dipercayai oleh masyarakat aboge sebagai hari dimana arwah dibebaskan dari siksakubur.

Dari tradisi jaroh makom ini nilai moral yang dapat diajarkan pada anak yakni nilai penghormatan. Dimana anak-anak yang diajak ziarah oleh orangtuanya secara tidak langsung diajarkan untuk menghormati sesepuh atau orang yang telah meninggal dunia dengan cara mengirimkan doa sebagai bentuk pemberian hadiah sekaligus pengharapan pertolongan.

Tradisi praktik yang dilakukan oleh warga desa Cikakak merupakan bagian kearifan lokal berupa kegiatan keagamaan, sosial dan budaya (Koentjaraningrat, 1990). Dalam proses mendidik moral melalui tradisi praktik ini peran orangtua sebagai pendidik yakni menjadi role model bagi anak (Rozaq, 2013), selain itu pengenalan kearifan lokal dan pendidikan nilai moral juga diajarkan secara langsaung melalui sebuah kegiatan bukan hanya cerita semata (Khaironi, 2017). 


\section{Tradisi Lisan}

Tradisi lisan merupakan sebuah tradisi yang diturunkan oleh nenek moyang atau sesepuh dalam bentuk perkataan atau ujaran-ujaran baik berupa perintah ataupun larangan (Koentjaraningrat, 2000). Adapun tradisi lisan yang dilakukan oleh orang tua guna mendidik moral anak usia dini yakni: 1) Tidak boleh duduk di pintu: Tradisi lisan tidak boleh duduk dipintu atau dalam bahasa jawanya "ora olih njagon nang tengah lawang" ini sering dikatakan oleh orang tua dulu pada anak agar anak tidak duduk di pintu karena hal tersebut tidak elok (ora ilok). Jika anak-anak duduk dipintu maka saat dewasa ia akan menjadi perawan tua/ menikah diusia tua dan rezekinya sempit. Hal ini sebenarnya mengajarkan anak agar anak tidak duduk di tengah pintu, karena pintu adalah tempat untuk lalu-lalang, sehingga jika anak duduk dipintu akan mempersulit orang yang lewat. 2) Tidak boleh buang air kecil di lubang; Anak-anak juga diajarkan untuk tidak membuang air kecil disembarang lubang. Hal tersebut karena ditakutkan di dalam lubang tersebut terdapat penghuninya atau makhluk yang hidup di dalam lubang tersebut. Baik makhluk hidup yang terlihat atau yang ghaib. Disisi lain hal ini sebenarnya orang tua mengajarkan nilai moral peduli alam atau lingkungan, agar anak tidak sembarang dalam membuang hajat agar tidak merusak lingkungan. 3) Tidak boleh keluar rumah waktu maghrib; Ajaran tidak boleh keluar rumah waktu maghrib diajarkan oleh oraang tua pada anak sejak dini. Dimana saat waktu maghrib tiba maka anak-anak harus masuk kedalam rumah. Hal ini karena jika anak-anak berada diluar rumah akan dibawa oleh hantu (cepet). Tujuan sebenarnya orang tua mengajarkan hal tersebut yakni agar anak tidak berkeliaran atau bermain diluar. Nilai moral yang diajarkan oleh orang tua pada anak yakni agar anak disiplin. Dimana anak diberi pilihan agar anak tetap tinggal di rumah atau ke mushola dan tidak bermain atau berkeliaran diluar rumah. 4) Makan harus dihabiskan; Tardisi lisan makan harus dihabiskan juga diajarkan pada anak dengan memberitahu pada anak agar apa yang dimakan dihabiskan, jika tidak dihabiskan maka hewan peliharaannya akan mati. Tradisi ini sebenarnya diajarkan oleh orang tua pada anak agar anak tidak serakah, mengambil makanan secukupnya serta tidak memubah-mubahkan makanan. Nilai moral yang diajarkan oleh orangtua pada anak dari tradisi lisan ini yakni, agar anak menghargai, tidak serakah dan bertanggung jawab. Hal ini ditunjukkan dengan konsep anak harus menghabiskan makanan yang telah dia ambil. 5) Tidak boleh berkata kotor; Tradisi lisan tidak boleh berkata kotor sering disebut juga dengan ora ulih ngomong saru. Tradisi ini diajarkan agar anak tidak berbicara tidak sopan atau yang jorok. Selain itu dengan diajarkan tradisi lisan ini anak diharapkan memiliki tatakrama berbicara yang baik dengan orang lian. Nilai moral yang diajarkan oleh orang tua pada anak terkait dengan tradisi tidak boleh berkata kotor yakni nilai jujur. 6) Tidak boleh mencuri; Ora ulih nyolong tradisi ini diajarkan oleh orang tua agar anak tidak berani mengambil apa yang bukan milik dan haknya. Selain itu agar anak memiliki moral yang baik saat dewasa. Nilai moral yang diajarkan oleh orang tua pada anak terkait dengan tradisi tidak boleh mencuri yakni nilai kejujuran.

Tradisi lisan bagi masyarakat desa Cikakak juga dikenal dengan sebutan pitutur leluhur (kata orang zaman dulu) dimana perkataan-perkataan tersebut dipercya dapat membawa dampak baik jika dilakukan dan akan berdampak buruk jika dilarang. Penggunaan tradisi lisan sering digunakan oleh orangtua dalam kehidupan sehari-hari. Orangtua sebagai pendidik memiliki pengarh yang sangat besar hal ini karena keluarga menjadi lingkungan eksternal anak yang pertama (M. Fitri \& Na'imah, 2020). Dalam mengajarkan tradisi lisan ini pada anak, biaanya orangtua akan menggunakan model ketegasan, orang tua tidak segan untuk memarahi anak ketika anak melanggar tradisi tersebut, dengan kata lain dalam hal ini peran guru sebagai pendidik juga berperan sbagai evaluator dan pengintervensi anak (Kirom, 2017). Dari hasil wawancara dengan Mbah Sulam selaku salah satu juru kunci, bahwasanya dengan anak diajari hal-hal (tradisi lisan) tersebut diharapkan anak memiliki moral yang baik, sehingga dapat melanjutkan cita-cita para leluhur. 


\section{SIMPULAN}

Orangtua sebagai peletak pondasi pertama dalam penanaman nilai pada anak memiliki peran yang sangat vital. Banyak hal yang mempengaruhi proses pendidikan yang dilakukan oleh orangtua pada anak, diantaranya adalah tradisi dan wilayah. Hasil dari penelitian ini menunjukkan bahwasanya pendidikan moral anak usia dini berbasis kearifan lokal dalam keluarga khususnya masyarakat Aboge desa Cikakak dilakukan melalui tradisi praktik dan tradisi lisan, dimana anak-anak dilibatkan dalam tradisi praktik berupa idul idhi, ganti jaro, rebo wekasan, sedekah bumi, dan jaroh makom, sedangkan tradisi lisan berupa perkataan yang diaplikasikan dalam kehidupan seharai-hari anak seperti tidak boleh duduk dipintu, makan harus dihabiskan, tidak boleh kencing dilubang, tidak boleh mencuri, ttidak boleh berbicara kotor dan tidak boleh keluar waktu maghrib. Adapun nilai moral yang diajarkan oleh orangtua melalui tradisi tersebut yakni nilai toleransi atau menghargai orang lain, kebersamaan dan saling berbagi, saling memaafkan, bekerjasama, gotong royong dan menghilangkan sifat iri, sombong (sifat buruk dalam diri), kepedulian (peduli pada alam), penghormatan (menghormati), jujur, tidak serakah, dan bertanggung jawab.

\section{UCAPAN TERIMA KASIH}

Ucapan terimakasih penulis sampaikan kepada seluruh pihak yang terlibat dalam proses penelitian ini, khususnya pihak keluarga yang menjadi subjek penelitian. Peneliti juga mengucapkan banyak terimakasih kepada pembimbing, serta pihak yang telah mendukung proses terbitnya artikel ini.

\section{DAFTAR PUSTAKA}

Ananda, S. (2021). Nilai - Nilai Kearifan Lokal Tari Campak Di Bangka Selatan Dan Implementasi Dalam Layanan Bimbingan Dan Konseling. Universitas Sriwijaya.

Barida, M. (2016). Pengembangan perilaku anak melalui imitasi. Jurnal Care Edisi Khusus Temu Ilmiah, 03(3), 13-20.

Boiliu, F. M., \& Polii, M. (2020). Peran Pendidikan Agama Kristen dalam Keluarga di Era Digital terhadap Pembentukan Spiritualitas dan Moralitas Anak. IMMANUEL: Jurnal Teologi Dan Pendidikan Kristen, 1(2), 76-91. https:// doi.org/10.46305/im.v1i2.18

Desmita. (2012). Psikologi Perkembangan. Remaja Rosdakarya.

Dokhi, M. (2016). Analisis Kearifan LokalDitinjau dari Keragaman Budaya. PDSPK Depdiknas.

Fitri, A. N., Riana, A. W., \& Fedryansyah, M. (2015). Perlindungan Hak-Hak Anak Dalam Upaya Peningkatan Kesejahteraan Anak. Prosiding Penelitian Dan Pengabdian Kepada Masyarakat, 2(1), 45-50. https:// doi.org/10.24198/jppm.v2i1.13235

Fitri, M., \& Na'imah, N. (2020). Faktor Yang Mempengaruhi Perkembangan Moral Pada Anak Usia Dini. Al-Athfaal: Jurnal Ilmiah Pendidikan Anak Usia Dini, 3(1), 1-15. https:// doi.org/10.24042/ajipaud.v3i1.6500

Khaironi, M. (2017). Pendidikan Moral Pada Anak Usia Dini. Jurnal Golden Age, 1(01), 1. https://doi.org/10.29408/goldenage.v1i01.479

Kirom, A. (2017). Peran Guru Dan Peserta Didik Dalam Proses Pembelajaran Berbasis $\begin{array}{llll}\text { Multikultural. } & \mathrm{Al} & \text { Murabbi, } & \text { 3(1), }\end{array}$

http://jurnal.yudharta.ac.id/v2/index.php/pai/article/view/893

Koentjaraningrat. (1990). Pengantar Ilmu Antropologi. Djambata.

Koentjaraningrat. (2000). . Pengantar Ilmu Antropologi. Rineka Cipta.

Medcom.id. (2021). Upaya Mencegah Kenakalan Remaja di Jakarta. Medcom.Id.

Miles, M. B. and A. M. H. (2005). Qualitative Data Analysis (terjemahan. UI Press.

Moleong, L. J. (2016). Metodologi Penelitian Kualitatif. PT Rosdakarya.

PDSPK. (2016). Analisis Kearifan Lokal Ditinjau Dari Keragaman Budaya. PDSPK Kemdikbud RI. 
Rachmawati, Y. (2020). Pengembangan Model Etnoparenting Indonesia pada Pengasuhan Anak. Jurnal Obsesi: Jurnal Pendidikan Anak Usia Dini, 5(2), 1150-1162. https://doi.org/10.31004/obsesi.v5i2.706

Ramadhan, M. C., Marlina, M., \& Isnaini, I. (2020). Pencegahan Terjadinya Tindak Pidana Nakotika pada Anak di Kelurahan Bantan Timur. Journal of Education, Humaniora and Social Sciences (JEHSS), 2(3), 540-553. https:// doi.org/10.34007/jehss.v2i3.115

Rozaq, A. (2013). Pendidikan Moral Anak Pilar Utama Dalam Keluarga. Jurnal Tarbawi, 10(2). Satya Yoga, D., Suarmini, N. W., \& Prabowo, S. (2015). Peran Keluarga Sangat Penting dalam Pendidikan Mental, Karakter Anak serta Budi Pekerti Anak. Jurnal Sosial Humaniora, 8(1), 46. https://doi.org/10.12962/j24433527.v8i1.1241

Surawati, N. M., Sri Winarti, N. N., \& Dwipayana, A. . P. (2019). Esensi Ajaran Moralitas Dalam Tutur Jatiswara. Dharmasmrti: Jurnal Ilmu Agama Dan Kebudayaan, 10(2), 53-59. https://doi.org/10.32795/ds.v19i2.427

Tridhonanto, A. (2014). Mengembangkan Pola Asuh Demokratis. Elex Media Komputindo.

Ulumudin, I. (2020). Pengembangan Model "Teknik Imitasi" Sebagai Terapi Dasar Untuk Anak Usia Dini Dengan Autisme. JIV-Jurnal Ilmiah Visi, 15(1), 41-52. https://doi.org/10.21009/JIV.1501.5

Wuryandani, W. (2010). Peranan Keluarga Dalam Menanamkan Nilai Moral Pada Anak Usia Dini. Diklus, 14(1), 76-85. 